\title{
The Effect of Computer Assisted I nstruction on Elementary Reading and Writing Achievement ${ }^{*}$
}

\author{
H. Gülhan ORHAN KARSAK ${ }^{* *}$
}

Received: 14 February 2013

Accepted: 28 May 2013

\begin{abstract}
The research investigated the effect of computer assisted instruction (CAI) on elementary reading and writing achievement (ERWA). The sample consisted of 64 first graders (32 in the experimental group and 32 in the control group) in the 2006-2007 academic year. This quasi-experimental study had a posttest only control group design and was conducted during the first semester. The experimental group was taught by CAI and the control group was taught by traditional instruction. Data were gathered through 'Parent Questionnaire', 'Reading Concepts Scale', 'Achievement Test', 'Reading and Handwriting Observation Form' and analyzed by chi-square, frequency and $t$ test through SPSS 12.0. The main findings of the study were as follows: (1) CAI affected first graders' handwriting, reading fluency and punctuation, (2) CAI didn't affect their writing and reading comprehension, (3) CAI affected ERWA of those who did not have any computer at home.
\end{abstract}

Keywords: Computer assisted instruction, elementary reading and writing instruction, reading comprehension, handwriting, academic achievement.

\section{Extended Abstract}

Purpose and Significance: Regarding results obtained by different researchers and inadequate number of studies in Turkey, it is significance to investigate positive and negative effects of computer assisted instruction on elementary reading and writing achievement. Additionally, it is necessary to create a model which can contribute elementary reading and writing practices. For these reasons, this study investigated the impact of computer assisted instruction (CAI) on elementary reading and writing achievement (ERWA). So, questions addressed in this study were as follows: (1) Does CAI have significant effect on first graders' reading fluency, handwriting, punctuation, writing, reading comprehension, and ERWA? (2) Does CAI have significant effect on ERWA of first graders who have a computer at home and of who do not have any computer at home?

Methods: The sample of the study consisted of two groups: the experimental group was composed of 32 first graders from 1-D and the control group comprised 32 first graders from 1-C in Kayisdagi Arifpasa Primary School, Kadikoy, Istanbul. This quasiexperimental study had a post-test only control group design and was conducted during the first semester. In the experimental group, courses were taught by CAI and courses in the control group were taught by traditional instruction. The 'Parent Questionnaire' was used to learn about reading, writing and computer skills before starting to attend the

*This study is a part of the author's master's thesis entitled, "The Effect of Computer Assisted Instruction on Elementary Reading and Writing Achievement” and completed at Marmara University.

***Yildiz Technical University, E-mail: gorhan811@gmail.com 
primary school. 'The Scale of Reading Concepts' was used learn about knowledge of first graders before starting to attend the primary school. To measure ERWA, 'Achievement Test' was administered both as a pre- and as a post-test. To measure first graders' reading fluency, 'Reding Observation Form' was used. To measure first graders' handwriting abilities, 'Hand Writing Observation Form' was utilized. To analyze the data, chi-square, frequency and t test were employed through SPSS 12.0.

Results: As stated in the first research question, the impact of CAI on reading fluency, handwriting, punctuation, writing, reading comprehension, and ERWA was investigated. Significant differences were found in favor of the experimental group with regard to handwriting $(t=5.190, p<0.05)$, punctuation $(t=3.900, p<0.05)$, reading fluency $(t=3.433, p<0.05)$, and ERWA $(t=2.888, p<0.05)$. In the second question, the impact of CAI on ERWA of first graders who have a computer at home and who do not have any computer at home was investigated. Significant differences were found in favor of first graders who do not have any computer at home $(t=2.316, p<0.05)$, but not of those who have a computer at home $(t=1.715, p>0.05)$.

Discussion and Conclusions: In this study, the impact of CAI on ERWA was investigated. Results showed that (1) CAI had impact on handwriting, punctuation and reading fluency, (2) CAI did not have impact on reading comprehension and writing, (3) CAI had impact on ERWA. Those were consistent with the existing literature (Anderson-Inman \& Horney, 1998; Barker \& Torgesen, 1995; Burns, Roe, \& Ross, 1996; Daal \& Reitsma, 2000; Grabe \& Grabe, 1996; Haugland, 1992; Kablan, 2001; Matthew, 1997; McKenna \& Watkins, 1996; Medwell, 1996; Mitchell \& Fox, 2001; Reitsma, 1988; Reitsma \& Wesselling, 1998; Wise, Olson, \& Treiman, 1990). In addition, (1) CAI did not have impact on ERWA of first graders who have a computer at home, (2) CAI had impact on ERWA of those who do not have any computer at home. This result can be explained with computer habits. That is, first graders who do not have any computer at home might pay more attention to and be more motivated in the course. They were less used to computers. Additionally, first graders who have a computer at home might be affected adversely by aimless and unsystematic use of computers. According to the findings, the following suggestions were proposed: (1) professional Website designers might design sites for teachers who will use CAI to teach elementary reading and writing so that pupils can do activities under teacher guidance. By access to the Internet in classrooms and information technology laboratories, pupils and teachers can benefit from those Websites. (2) Coursebooks to be used in teaching elementary reading and writing might be developed in congruence with compact disks to be used. The sets of compact disks which support preparation and learning elementary reading and writing might be delivered to schools with coursebooks. 


\title{
Bilgisayar Destekli Öğretimin İlkokuma Yazma Başarısına Etkisi *
}

\author{
H. Gülhan ORHAN KARSAK ${ }^{* *}$
}

Makale Gönderme Tarihi: 14 Şubat 2013

Makale Kabul Tarihi: 28 May1s 2013

ÖZET: Bu çalışmada bilgisayar destekli öğretimin ilkokuma yazma başarısına etkisi incelenmiştir. Son-test kontrol gruplu desene sahip bu araştırma yarı deneysel bir çalışmadır. Araştırmanın çalışma grubunu deney grubunda 32, kontrol grubunda 32 öğrenci olmak üzere toplam 64 ilköğretim 1.sınıf öğrencisi oluşturmuştur. Uygulama, deney grubunda bilgisayar destekli öğretimle yürütülürken kontrol grubunda geleneksel öğretimle sürdürülmüştür. Veriler, "Veli Anketi”, “Okuma Kavramları Ölçeği”, "Başarı Testi”, “Okuma Değerlendirme Formu” ve "Yazı Değerlendirme Formu" ile toplanmış ve ki kare, frekans ve $t$ testi ile analiz edilmiştir. Elde edilen bulgulara göre bilgisayar destekli okuma yazma öğretimi gören öğrenciler ile geleneksel öğretim görenlerin yazı, noktalama ve okuma başarılarında anlamlı fark bulunmuş ancak okuduğunu anlama ve yazma başarılarında anlamlı bir fark bulunmamıştır. Genele bakıldığında ilkokuma yazma başarılarında anlamlı fark bulunmuştur. Evinde bilgisayar olmayan deney ve kontrol grubu öğrencilerinin ilkokuma yazma başarılarında anlamlı fark bulunmuş ancak evinde bilgisayar olanların ilkokuma yazma başarılarında anlamlı bir fark bulunmamıştır. Sonuçlar, farklı yazarların araştırma sonuçları incelenerek tartışılmıştır.

Anahtar sözcükler: Bilgisayar destekli öğretim, ilkokuma yazma öğretimi, okuduğunu anlama, yazı, akademik başarı.

\section{Giriş}

İlköğretimde eğitim-öğretimin başlangıcı ve en hassas süreci okuma yazma öğretimidir çünkü okuma yazma; insanların öğrenmeyi sürdürmelerini, kendilerini ifade etmelerini ve çevrelerini bilgilendirmelerini sağlayarak ekonomik, sosyal ve kültürel yönden gelişimini etkiler (Güneş, 2005). Yalnızca bireysel gelişimi değil, bireyin içinde bulunduğu ailenin, ailenin içinde bulunduğu toplumun, giderek ulusun ve dünyanın gelişmesinde de belirleyici olur.

$\mathrm{Bu}$ nedenle okuma yazma, çocukları dünyaya ayak uydurmak üzere sosyal yaşama hazırlayan okul programlarının omurgasını oluşturur. Okul programları içerisinde hemen her derste okuma yazmanın önemli bir yeri vardır. Nitelikli okuyamayan, okuduğunu tam olarak anlayamayan ve yazma becerisi gelişmemiş öğrencilerin okulda hatta hayatta başarılı olacağı söylenemez. Şenol (2001) ilk sınıflarda sağlam bir okuma yazma becerisi kazanamamış kişinin anlatımının da zayıf olacağından ve ileri sınıflarda materyallerden gereği kadar yararlanamayacağından, Mathes, Denton, Fletcher, Anthony, Francis ve Schatschneider (2005) ise bu zayıflıkta uygun öğretim yöntemlerinin kullanılmamasının etkisinden söz eder. Ayrıca, Cunningham ve Stanovich (1998) ile Echols, West, Stanovich ve Zehr (1996) de gerçekleştirdikleri çalışmalarında birinci sınıfta zayıf okuyan çocukların okuma yazma ile ilgili problemler yaşamaya devam ettikleri, okumada daha becerikli olan akranlarından daha az okudukları sonuçlarına ulaşarak ilkokuma yazma öğretiminin önemini bir kez daha ortaya koymuşlardır. Torgesen ve Burgess (1998) de 1. sınıfta

*Bu çalışma, yazarın Marmara Üniversitesi'nde hazırladığı "Bilgisayar Destekli Öğretimin İlkokuma Yazma Başarısına Etkisi" başlıklı yüksek lisans tezinden üretilmiştir.

** Yıldız Teknik Üniversitesi, E-posta: gorhan811@gmail.com 
zayıf okuyan çocukların ilkokulun sonunda orta düzey okuma becerisine dahi erişemediklerini belirterek bu fikri destekler.

Tüm bu sorunlar zeka, yaş (Calp, 2003) sağlık durumu (Savaş, 2006), ailenin ilgisi (Çakır, 2004; Yiğit, 2007) ve sosyoekonomik düzeyi (Gönen, Öncü, \& Işıtan, 2004; Yılmaz, 1995), okul öncesinde alınan eğitimin niteliği (Brooks, 2000; Cooper, 1997; Koç, Taylan, \& Bekman, 2002) gibi etkenlerden kaynaklanabilir. Bunların yanı sıra şüphesiz okuma yazma öğretiminde en önemli etki kaynakları öğrenme ortamı ve öğretim yöntem ve teknikleridir (Connor, Son, Hindman, \& Morrison, 2005). Clark (1991) pek çok öğretim yönteminin çok sayıda bilgisayar teknolojisi ile desteklenebileceğini fakat öğretim yöntemlerini kontrol altına almanın başarıyı sağlamak için önemli olduğunu vurgular. Kontrolü sağlamanın yollarından biri öğretim etkinliklerini uygun araçlarla planlayarak somutlaştırmaktır. $\mathrm{Bu}$ durumun aksine öğretmenlerin okuma yazma öğretirken bu yaş çocuklarının somut yaşantılar döneminde birer oyun çocuğu olduklarını unutup soyut etkinlikler uyguladıkları sıklıkla gözlemlenir. Oysa Paivio (2006) okumayı henüz yeni öğrenen öğrenciler için soyut olan kelimeler görselleri ile verilerek somutlaştırıldığında, öğrencilerin okuma şifresini daha çabuk çözeceklerini belirtir. 2005 İlköğretim (1-5. Sınıflar) Türkçe dersi öğretim programında da ilkokuma yazma öğretimi sürecinde somut ögelerden yararlanılarak kısa sürede cümlelere ulaşılması vurgulanmıştır (Milli Eğitim Bakanlığı, 2005). Programın somut öge vurgusu ve 1. sınıf öğrencisinin oyun eğiliminin yanı sıra dikkat süresinin kısa oluşu hatırlandığında (Akyol, 2005; Calp, 2003; Tortop, 2003) ilkokuma yazma öğretim içeriğinin, anlamlı ve düzeye uygun oyunlar, sabit ve hareketli görseller içeren farklı materyallerle planlanarak sunulmasının önemi daha iyi anlaşılacaktır. Bu sunum için en uygun yol, öğretimin bilgisayar desteğiyle gerçekleştirilmesidir.

Cotton (1991) öğretimde bilgisayarın bir destek araç olarak kullanıldığ1 bilgisayar destekli öğretimi, öğretmen rehberliğinde bire-bir, alıştırma, uygulama ve benzeşim programları ile hazırlanan etkinlikler olarak ifade eder. Friend ve Cole (1990) bilgisayar destekli öğretimin yararlarına odaklanarak bireysel olarak yararlanılabilen, programları takip ederek kendi hızında tekrarı destekleyen ve benzeşimler kullanılan bir sistem olarak tanımlar. Yalın (2003) da bir sistem olarak gördüğü bilgisayar destekli öğretimin bilgisayarların sistem içine programlanan dersler yoluyla bir konu ya da kavramı öğretmek ya da önceden kazandırılan kazanımları pekiştirmek amacıyla kullanılması olarak ifade eder. Öyle ki bilgisayar teknolojisi ilkokuma yazma öğrenmede öğrencilerin dikkatini artıracak önemli bir öğrenme aracıdır ve bu teknolojinin İnternetten bilgiye ulaşılmasını sağlayan inanılmaz bir kapasitesi vardır. Gambrell, Morrow ve Pennington (2000) de ilkokuma yazma öğretiminde öğretim programına ve tekniklerine uygun olarak hazırlanmış yazılımların yer aldığı CD’lerden, animasyonlu video kliplerden, sunulardan, elektronik ortamda hazırlanmış çalışma kâğıtlarından ve İnternetteki ilkokuma yazma öğretiminde kullanılabilecek sitelerden yararlanarak öğrencilerin ilgisini çekerek ve motivasyonlarını artırarak zevkli ve eğlenceli bir öğrenme ortamı sağlanacağını ifade eder. Böylece belirtilen niteliklere sahip düzenli bir ilkokuma yazma öğretimi görecek 1. sınıf öğrencileri için bireysel 
farklılıklar nedeniyle doğabilecek öğretim ve öğrenme güçlüklerini aşmak da kolaylaşacaktır.

Bilgisayar destekli ilkokuma yazma öğretimi ile öğrenciler harflerin yazımı ve sesi hakkında doğru bilgiye ulaşacaktır. Özellikle sesleri tanıma ve hissetme aşamasında, çocuk için soyut olan harfleri görsellerle ve çeşitli nesnelerin sesleriyle desteklemek, her harfin kavratılmasıyla ilgili değişik senaryolar sunmak, açık heceye ulaşmayı kolay kavratmak için bilgisayar teknolojileri kullanımı ile öğretim yöntemleri çeşitlendirilebilecektir. Bilgisayar destekli öğretim öğrencilerin sesleri, kelimeleri, heceleri, cümleleri öğrenirken bunların okunuşları, yazılışları, anlamları hakkında doğru bilgiye ulaşmalarında ve bunlar arasındaki benzerlikleri ve farklılıkları hissetmelerinde yardımcı olacaktır.

Ek olarak ilkokuma yazma öğretiminde bilgisayar desteğiyle farklı materyallerin kullanımı, öğrencileri yaratıcılığa sevk ederek ve aşamalı öğrenmeyi kolaylaştırarak onları aktif hâle getirecektir (Rıza, 1997). Kulik (1994) bilgisayar destekli öğretime ilişkin gerçekleştirdiği sekiz meta-analizi çalışması sonucunda yöntemin öğrencilerin öğrenmelerini yüzde 50'den yüzde 64'e kadar artırdığını raporlamıştır. Benzer olarak alanyazında pek çok araştırma bilgisayar desteğinin ilkokuma yazma başarısını artırdığını ifade eder. Örneğin; Hollanda'da Reitsma ve Wesselling (1998) tarafından hazırlanan bir yazılımla ilkokul 1. sınıf öğrencilerine sesler öğretilmiştir. Bu öğrencilerin, yazılımla öğretim görmeyen sınıf arkadaşları ile kıyaslandıklarında, okuma yazma başarılarının arttığı görülmüştür. Reitsma'nın Daal (2000) ile birlikte yürüttüğü bir başka çalışmasında ise bilgisayar destekli öğretim yapılan öğrencilerin, yapılmayanlara göre sesleri daha çabuk tanıyabildikleri ve daha fazla kelime okuyabildikleri sonucuna ulaşılmıştır. Benzer olarak Mitchell ve Fox (2001) okuma sorunu yaşayan 1. sınıf öğrencilerinden bir gruba karıştırdıkları sesleri öğretmek için hazırlanan bir yazılımı kullanmıştır. Sonuçta bu öğrencilerin okuma becerilerinin geliştiği görülmüştür. Diğer gruba ise bilgisayar desteği olmadan çalışmalar yaptırılmış ve okuma yazma becerilerinde gelişme görülmemiştir. Bir sonraki y1lda okuma sorunu olmayan 1. sınıf öğrencileri için aynı yazılım kullanılmış ve bu öğrencilerin de okuma becerilerinin geliştiği görülmüştür. Ülkemizde ise Kablan (2001) tarafından hazırlanan PowerPoint sunularının öğrenciler için ilgi ve dikkat çekici olduğu, bu tür materyallerin yazma becerisinin gelişimi için yeterli olmasa da çizgi şekilleri ve çiziliş yönlerini gösterme, cümle analizi ve sentez çalışmalarında etkili kullanılabileceği sonucuna ulaş1lmıştır. Yalçın (2006) ise ilkokuma yazma öğretimi için sesli komutlarla kontrol edilebilen bir yazılım geliştirmiştir. Hazırlanan yazılım ile etkili bir öğretim süreci düşünülmüştür.

Farklı yazarlar tarafından ulaşılan sonuçlar dikkate alındığında ve ülkemizde alandaki araştırma sayısının yurtdışı ile karşılaştırıldığında yetersiz olduğu gerçeği düşünüldüğünde bilgisayar destekli ilkokuma yazma öğretiminin, öğrencinin ilkokuma yazma başarısındaki olumlu ve olumsuz etkilerini belirgin bir biçimde ortaya koymak önemli gözükmektedir. Ayrıca, öğretmenler için ilkokuma yazma öğretimi çalışmalarına katkı sağlayan bir model oluşturmak bir ihtiyaç teşkil etmektedir. Bu nedenle çalışmada 
ilköğretim birinci sınıfta Türkçe dersi ilkokuma yazma öğretiminde bilgisayar destekli öğretimin öğrencinin ilkokuma yazma başarısına etkisi araştırılmıştır. Bu genel amaç doğrultusunda aşağıdaki sorulara cevap aranmıştır:

1. Bilgisayar destekli öğretimin; ilköğretim birinci sınıf öğrencilerinin okuduğunu anlama, yazı, noktalama, yazma, okuma ve ilkokuma yazma toplam başarısına etkisi var mıdır?

2. Evlerinde bilgisayar olan ve olmayan gruplarda, bilgisayar destekli öğretimin ilkokuma yazma başarısına etkisi var mıdır?

\section{Yöntem}

\section{Araştırma Modeli}

$\mathrm{Bu}$ araştırma, yarı deneysel modellerinden "son-test kontrol gruplu model”e göre desenlenmiş ve alanda gerçekleştirilmiştir. Son-test kontrol gruplu modelde iki grup bulunur. Bunlardan biri deney, öteki kontrol grubu olarak kullanılır. Gruplara yalnızca son-test uygulanır. Çoğu denemelerde ön-testin uygulanması ya olanaksız ya da gereksizdir (Karasar, 2005). Bu nedenle grupların son-test puanlarına bakılarak farklılığın hangi grup lehine olduğuna karar verilir. Deney ve kontrol gruplarındaki öğrencilerin ortalama puan farklılı̆̆ına ve sonuçların hangi grup lehine olduğuna bakılarak uygulamanın etkililiğine karar verilir (Willis, 2008).

\section{Çalışma Grubu ve Denklik İşlemleri}

Araştırmanın katılımcılarını, İstanbul ili Kadıköy ilçesi Kayışdağı Arifpaşa İlköğretim Okulu 2006-2007 eğitim-öğretim yılında birinci sınıf şubeleri arasından deney grubu olarak seçilen 1-D şubesindeki 32 öğrenci ile kontrol grubu olarak seçilen 1-C sınıfındaki 32 ögrenci oluşturmuştur.

Çalışmada, uygulama ilköğretim birinci sınıf öğrencilerine ve ilkokuma yazma öğretimi üzerine yapılacağından ön-test gereksiz görülmüştür. Bu bağlamda Öztunç (1994) tarafından Türkçeye uyarlanan “Okuma Kavramları Ölçeğì” ile öğrencilerin okula başlamadan önce sahip oldukları okuma ve yazma kavramları tespit edilerek gruplar bu açıdan eşitlenmeye çalışılmıştır. Veli anketi ile öğrencilerin okula başlamadan sahip oldukları bilgisayar becerileri tespit edilerek gruplar bu açıdan da eşitlenmeye çalışılmıştır. Grupların cinsiyet karşılaştırmasından elde edilen dağılım Tablo 1'de gösterilmiştir. 
Tablo 1

Kontrol ve Deney Grubu Öğrencilerinin Cinsiyetlerini Karşılaştırmaya İlişkin Değerler

\begin{tabular}{lcccc}
\hline Gruplar & \multicolumn{4}{c}{ Cinsiyet } \\
\hline \multirow{2}{*}{ Kontrol } & \multicolumn{5}{c}{ Kiz } & Erkek & Toplam \\
& $N$ & 19 & 13 & 32 \\
\hline Deney & $\%$ & 59.4 & 40.6 & 100 \\
& $N$ & 17 & 15 & 32 \\
Toplam & $\%$ & 53.1 & 46.9 & 100 \\
& $N$ & 36 & 28 & 64 \\
& $\%$ & 56.3 & 43.8 & 100 \\
\hline
\end{tabular}

Tablo 1'e göre kontrol grubunda yer alan kız öğrencilerin oranı \% 59.4 iken, deney grubunda yer alan kız öğrencilerin oranı kontrol grubundakilerin oranına yakındır ve \% 53.1'dir. Kontrol grubunda yer alan erkek öğrencilerin oranı \% 40.6 iken, deney grubunda yer alan erkek öğrencilerin oranı kontrol grubundakilerin oranına yakındır ve \% 46.9'dur. Bu durumda kontrol ve deney gruplarının cinsiyete göre dağılımının eşit olduğu görülmektedir.

Kontrol ve deney grubu öğrencilerinin “Okuma Kavramları Ölçeği”nden aldıkları toplam puan ortalamaları arasında anlamlı bir farkın bulunup bulunmadığını karşılaştırmak üzere yapılan $t$ testinden elde edilen dağılım Tablo 2'de gösterilmiştir.

Tablo 2

Kontrol ve Deney Grubu Öğrencilerinin Okuma Kavramları Ölçeği Toplam Puanlarını Karşılaştırmaya İlişkin Değerler

\begin{tabular}{lcccccc}
\hline Gruplar & $N$ & $x$ & ss & $t$ & $s d$ & $p$ \\
\hline Kontrol & 32 & 6.09 & 2.51 & \multirow{2}{*}{.609} & \multirow{2}{*}{62} & $.545^{*}$ \\
Deney & 32 & 6.53 & 3.19 & & \\
\hline
\end{tabular}

$* p>.05$

Tablo 2'ye göre yapılan $t$ testi analizi sonucunda kontrol ve deney gruplarının, öğrencilerin okula başlamadan önce sahip oldukları okuma ve yazma kavramları ile ilgili “Okuma ve Yazma Kavramları Ölçeği”nden aldıkları toplam puanları arasında fark olmadığı görülmektedir. ( $p>.05)$. Bu durumda son-test olarak verilecek başarı sınavı puanlarında gözlenen farklar, bilgisayar destekli öğretimin ilkokuma yazma başarısına etkisine bağlanabilecektir.

Kontrol ve deney grubu öğrencilerinin okula başlamadan önce bilgisayar becerilerinin eşit olup olmama durumunu tespit amacıyla öğrenci velilerinin çocuklarına okula başlamadan bilgisayar öğretmek için özel çaba sarfetme durumu karşılaştırılmıştır. Yapılan ki-kare analizinden elde edilen dağılım Tablo 3'te gösterilmiştir. 
Tablo 3

Kontrol ve Deney Grubu Öğrencilerinin Velilerinin Okula Başlamadan Çocuklarına Bilgisayar Öğretmek Iç̧in Özel Çaba Sarfetme Durumunu Karşılaştırmaya İlişkin Değerler

\begin{tabular}{llccc}
\hline Gruplar & \multicolumn{3}{c}{ Özel Çaba Sarfetme } \\
\hline \multirow{2}{*}{ Kontrol } & $N$ & Hayır & Evet & Toplam \\
& $\%$ & 28 & 4 & 32 \\
\multirow{2}{*}{ Deney } & $N$ & 87.5 & 12.5 & 100 \\
& $\%$ & 26 & 6 & 32 \\
\multirow{2}{*}{ Toplam } & $N$ & 81.3 & 18.8 & 100 \\
& $\%$ & 54 & 10 & 64 \\
& & 84.4 & 15.6 & 100 \\
\hline
\end{tabular}

$x^{2}=0.474, s d=1, p=0.491$

Tablo 3'e göre kontrol grubu öğrencilerinin \% 12.5'ine bilgisayar öğretmek için özel çaba sarfedilirken, deney grubunun \% $18.8^{\prime}$ ine özel çaba sarfedilmiştir. Kontrol grubu öğrencilerinin \% 87.5'ine okula başlamadan önce bilgisayar öğretmek için özel çaba gösterilmezken, deney grubunun \% 81.3'üne özel çaba gösterilmemiştir. Grupların okula başlamadan önce velilerinin çocuklarına bilgisayar öğretmek için özel çaba sarfetme durumuna göre dağılımlarının eşit olduğu görülmektedir $\left(x^{2}=0.474, s d=1, p>\right.$ .05). Bu durumda son-test olarak verilecek başarı sınavı puanlarında gözlenen farklar, bilgisayar destekli öğretimin ilkokuma yazma başarısına olan etkisine bağlanabilecektir.

\section{Veri Toplama Araçları}

Araştırmada verilerin toplanması için beş veri toplama aracı kullanılmıştır:

Veli Anketi. Öğrencilerin cinsiyetlerini, annelerinin ve babalarının eğitim durumlarını, okul öncesi eğitim alıp almadıkları, evlerinde bilgisayar olup olmadığı ve ilköğretim birinci sınıfa başlamadan önce sahip oldukları okuma yazma ve bilgisayar bilgi ve becerilerini belirlemek üzere toplam 19 maddeden oluşmuştur.

Okuma Kavramları Ölçeği. Öğrencilerin ilköğretim birinci sınıfa başlamadan okuma yazma kavramlarını bilme düzeylerini belirlemek amacıyla Öztunç (1994) tarafından hazırlanan "Okuma Kavramları Ölçeği” kullanılmıştır. Okuma ve yazma kavramlarını içeren ölçek 24 maddeden oluşmaktadır. Öztunç, ölçeğin Türkçe’ye uyarlanması için yapılan güvenirlik çalışmasında, içtutarlık ölçütüne başvurulduğunu; ölçek maddelerinin iç tutarlığı ve benzeşikliğini gösteren alfa değerlerinin Kuder Richardson 20 formülünün genelleştirilmiş formu ile saptandığını belirtmektedir. Bu nedenle ölçeğin iç tutarlığının kabul edilebilir boyutlarda görüldüğünü vurgulamıştır. Ölçeğin yapı geçerliği, kitapla ilgili kavramlar, yazının yönüne ilişkin kavramlar, harf ve kelime kavramları, yazıya ilişkin ileri düzeydeki kavramlar açısından incelenerek uygun bulunmuştur. Doğru olan her maddeye "1" puan, yanlış olan her maddeye "0" puan verilmekte, tüm ölçek 24 puan üzerinden değerlendirilmektedir. 
İlk Okuma Yazma Başarı Testi. Başarı testi örneği, ilköğretim birinci sınıfı okutmakta olan beş sınıf öğretmeninin görüşüne sunulmuştur. Öğretmenlerden olumlu görüşler alınması üzerine başarı testi, İstanbul ili Sultanbeyli ilçesi Türk Hava Kurumu Gazi İlköğretim Okulu'na devam eden on ilköğretim birinci sınıf öğrencisine pilot olarak uygulanmıştır. Pilot uygulama sonucunda başarı testi örneğinin öğrencilerin seviyelerine uygun olduğu görülmüştür. Başarı testi örneğine ilişkin öğretmen ve öğrenci görüşleri olumlu olduğu için bu testing deney ve kontrol grubundaki öğrencilerin ilkokuma yazma başarılarını belirlemek üzere başarı testi olarak uygulanmasına karar verilmiştir. Başarı testi okuduğunu anlama, noktalama, yazı, yazma ve sesli okuma olmak üzere beş bölüm olarak düzenlenmiştir. İlkokuma yazma başarısı; beş bölümden oluşan başarı testi ile yazı ve okuma değerlendirme formları ile toplam 46 puan üzerinden değerlendirilmiş̧tir.

Sesli Okuma Becerisi Değerlendirme Formu. İlköğretim Türkçe (1-5) dersi 1. sınıf programında okuma becerilerinin değerlendirilmesine ilişkin yer alan gözlem formundan ve birinci sınıf öğretmen görüşlerinden yararlanılarak "Sesli Okuma Becerisi Değerlendirme Formu" oluşturulmuştur. Yapılabilen her beceri "1" puan, yapılamayan her beceri " 0 " puan ile değerlendirilmiştir. Başarı testine dayanılarak doldurulan gözlem formundan elde edilen okuma becerisi toplam puanı, 10 puan üzerinden değerlendirilmiştir.

Yazı Becerisi Değerlendirme Formu. İlköğretim Türkçe (1-5) dersi 1. sınıf programında okuma becerilerinin değerlendirilmesine ilişkin yer alan gözlem formundan ve birinci sınıf öğretmen görüşlerinden yararlanılarak "Yazı Becerisi Değerlendirme Formu" oluşturulmuştur. Yapılabilen her beceri "1" puan, yapılamayan her beceri "0" puan ile değerlendirilmiştir. Başarı testine dayanılarak doldurulan değerlendirme formundan elde edilen yazı becerisi toplam puanı, 6 puan üzerinden değerlendirilmiştir.

\section{İşlem}

İşlem öncesinde deney ve kontrol grubu öğretmenine araştırmanın amacı ve konusu, veri toplama araçları ile ilgili bilgiler verilmiş, ayrıca, deney grubu öğretmenine çeşitli İnternet sitelerindeki PowerPoint programında hazırlanan sunumların, flash programında hazırlanmış animasyonların ve oyunların, Edusoft Yayıncılık tarafından yayınlanmış "Nasreddin Hoca ile Okuma Yazma Öğreniyorum" yazılımının ve Atlas Pazarlama Yayınlarına ait "İlkokuma Yazma Öğreniyorum" CD setinin kullanımını içeren uygulama planı ve bir dönem süresince yürütülmesi ile ilgili bilgiler de verilmiştir. Öğrencilere okuma kavramları ölçeği ve velilere öğrencilerin okuma yazma ve bilgisayar becerilerini tespite yönelik anket uygulanmıştır. İşlem sürecinde deney grubunda hazırlanan plan doğrultusunda bilgisayar destekli öğretimle ilkokuma yazma öğretilirken, kontrol grubunda geleneksel öğretim yapılmıştır. Öğrencilere son-test olarak ilkokuma yazma başarı testi uygulanmış, uygulayıcı öğretmenler tarafından gruplarındaki her bir öğrenci için okuma ve yazı değerlendirme formu doldurulmuştur. 


\section{Verilerin Çözümlenmesi}

Çalışmada veri toplama araçlarından elde edilen verilerin analizi için SPSS 12.0 paket programı kullanılmış, deney ve kontrol gruplarının dağılımlarının eşit olup olmadığını sınamak için frekans ve ki-kare; başarı ortalamaları arasındaki farkların anlamlı olup olmadığını sınamak için $t$ testi yapılmıştır.

\section{Bulgular}

Verilerin analizi sonucunda elde edilen bulgular, genel amaç ve alt amaçlar doğrultusunda aşağıda sunulmuştur.

\section{Kontrol ve Deney Gruplarının İlk Okuma Yazma Başarılarının Karşılaştırması}

Kontrol ve deney gruplarının okuduğunu anlama başarıları arasında anlamlı bir farkın olup olmadığına ilişkin yapılan karşılaştırma Tablo 4'te gösterilmiştir.

Tablo 4

Grupların Okuduğunu Anlama Başarılarının Karşılaştırılmasına İlişkin Bulgular

\begin{tabular}{lccccccc}
\hline & Gruplar & $N$ & $x$ & ss & $t$ & sd & $p$ \\
\hline $\begin{array}{l}\text { Okuduğunu } \\
\text { Anlama }\end{array}$ & Kontrol & 32 & 4.59 & 1.70 & .988 & 62 & $.327^{*}$ \\
& & & & & & & \\
\hline
\end{tabular}

$* p>.05$

Tablo 4'e göre bilgisayar destekli öğretim yapılan deney ve geleneksel öğretim yapılan kontrol grubundaki öğrencilerin okuduğunu anlama başarısı aritmetik ortalamaları arasında anlamlı bir fark bulunamamıştır. Okuduğunu anlama başarısında yapılan $t$ testi analizi sonucu anlamlı bir fark görülmemesine rağmen deney grubunun okuduğunu anlama puan ortalaması $(x=5.03)$, kontrol grubununkinden $(x=4.59)$ yüksektir.

Kontrol ve deney gruplarının yazı başarıları arasında anlamlı bir farkın olup olmadığına ilişkin yapılan karşılaştırma Tablo 5 'te gösterilmiştir.

Tablo 5

Grupların Yazı Başarılarının Karşılaştırılmasına İlişkin Bulgular

\begin{tabular}{lllccccc}
\hline & Gruplar & $N$ & $x$ & $s s$ & $t$ & $s d$ & $p$ \\
\hline Yaz1 & Kontrol & 32 & 3.68 & 1.35 & 5.190 & $.000 *$ & \\
& Deney & 32 & 5.21 & 0.97 & & & \\
\hline
\end{tabular}

$* p<.001$

Tablo 5'e göre bilgisayar destekli öğretim yapılan deney grubundaki öğrenciler ile geleneksel öğretim yapılan kontrol grubu öğrencilerinin yazı başarısı aritmetik ortalamaları arasında deney grubu lehine anlamlı bir fark bulunmuştur. 
Kontrol ve deney gruplarının noktalama başarıları arasında anlamlı bir farkın olup olmadığına ilişkin yapılan karşılaştırma Tablo 6' da gösterilmiştir.

Tablo 6

Grupların Noktalama İşaretlerini Kullanma Başarılarının Karşılaştııllmasına İlişkin Bulgular

\begin{tabular}{lllccccc}
\hline & Gruplar & $N$ & $x$ & ss & $t$ & $s d$ & $p$ \\
\hline \multirow{2}{*}{ Noktalama } & Kontrol & 32 & 2.71 & 1.61 & 3.900 & 62 & $.000^{*}$ \\
& Deney & 32 & 4.25 & 1.52 & & & \\
\hline
\end{tabular}

$* p<.001$

Tablo 6'ya göre bilgisayar destekli öğretim yapılan deney grubundaki öğrenciler ile geleneksel öğretim yapılan kontrol grubu öğrencilerinin noktalama işaretlerini kullanma başarısı puan ortalamaları arasında deney grubu lehine anlamlı bir fark bulunmuştur.

Kontrol ve deney gruplarının yazma başarıları arasında anlamlı bir farkın olup olmadığına ilişkin yapılan karşılaştırma Tablo 7'de gösterilmiştir.

Tablo 7

Grupların Yazma Başarılarının Karşılaştırılmasına İlişkin Bulgular

\begin{tabular}{lllccccc}
\hline & Gruplar & $N$ & $x$ & $s s$ & $t$ & $s d$ & $p$ \\
\hline \multirow{2}{*}{ Yazma } & Kontrol & 32 & 8.43 & 5.51 & 1.346 & 62 & $.183^{*}$ \\
& Deney & 32 & 10.40 & 6.16 & & & \\
\hline
\end{tabular}

$* p>.05$

Tablo 7’ye göre bilgisayar destekli öğretim yapılan deney grubundaki öğrenciler ile geleneksel öğretim yapılan kontrol grubu öğrencilerinin yazma başarısı puan ortalamaları arasında anlamlı bir fark bulunamamıştır.

Yazma başarısında, yapılan $t$ testi analizi sonucu anlamlı bir fark görülmemesine rağmen deney grubunun yazma puanı ortalaması ( $x=10.40)$, kontrol grubununkinden $(x$ $=8.43$ ) yüksektir.

Kontrol ve deney gruplarının sesli okuma başarıları arasında anlamlı bir farkın olup olmadığına ilişkin yapılan karşılaştırma Tablo 8'de gösterilmiştir.

Tablo 8

Grupların Sesli Okuma Başarılarının Karşılaştırılmasına İlişkin Bulgular

\begin{tabular}{llcccccc}
\hline & Gruplar & $N$ & $x$ & ss & $t$ & sd & $p$ \\
\hline $\begin{array}{l}\text { Sesli } \\
\text { Okuma }\end{array}$ & Kontrol & 32 & 2.78 & 2.28 & 3.433 & 62 & $.001^{*}$ \\
& Deney & 32 & 4.90 & 2.65 & & & \\
\hline
\end{tabular}

${ }^{*} p<.001$ 
Tablo 8'e göre bilgisayar destekli öğretim yapılan deney grubu öğrencileri ile geleneksel öğretim yapılan kontrol grubu öğrencilerinin sesli okuma başarısı aritmetik ortalamaları arasında deney grubu lehine anlamlı bir fark bulunmuştur.

Kontrol ve deney gruplarının ilkokuma yazma toplam başarıları arasında anlamlı bir farkın olup olmadığına ilişkin yapılan karşılaştırma Tablo 9' da gösterilmiştir.

Tablo 9

Grupların İlkokuma Yazma Toplam Başarılarının Karşılaştırılmasına İlişkin Bulgular

\begin{tabular}{llcccccc}
\hline & Gruplar & $N$ & $x$ & ss & $t$ & sd & $p$ \\
\hline $\begin{array}{l}\text { İlkokuma } \\
\text { Yazma }\end{array}$ & Kontrol & 32 & 22.21 & 10.01 & 2.888 & 62 & $.005^{*}$ \\
& Deney & 32 & 29.65 & 10.5 & & & \\
\hline
\end{tabular}

$* p<.05$

Tablo 9'a göre bilgisayar destekli öğretim yapılan deney grubundaki öğrenciler ile geleneksel öğretim yapılan kontrol grubu öğrencilerinin ilkokuma yazma toplam başarı puan ortalamaları arasında deney grubu lehine anlamlı bir fark bulunmuştur.

Kontrol ve deney gruplarının evlerinde bilgisayar olup olmama durumuna göre ilkokuma yazma başarılarında anlamlı bir farkın olup olmadığına ilişkin yapılan karşılaştırma Tablo 10'da gösterilmiştir.

Tablo 10

Grupların Evlerinde Bilgisayar Olup Olmama Durumuna Göre İlkokuma Yazma Başarılarının Karşılaştırılmasına İlişkin Bulgular

\begin{tabular}{llcccccc}
\hline $\begin{array}{l}\text { Bilgisayar } \\
\text { Durumu }\end{array}$ & Gruplar & $N$ & $x$ & ss & $t$ & sd & $p$ \\
\hline Var & Kontrol & 6 & 19.33 & 10.07 & 1.715 & 12 & .112 \\
& Deney & 8 & 30.12 & 12.65 & & & \\
Yok & Kontrol & 26 & 22.88 & 10.08 & 2.316 & 48 & $.025^{*}$ \\
& Deney & 24 & 29.50 & 10.09 & & & \\
\hline
\end{tabular}

${ }^{*} p<.05$

Tablo 10’a göre bilgisayar destekli öğretim yapılan deney grubundaki evlerinde bilgisayar olan öğrenciler ile geleneksel öğretim yapılan kontrol grubundaki evlerinde bilgisayar olan öğrencilerin ilkokuma yazma başarısı aritmetik ortalamaları arasında anlamlı bir fark bulunamamıştır ( $p>.05$ ). Evinde bilgisayar olan deney ve kontrol grubu öğrencilerinin ilkokuma yazma başarıları arasında anlamlı bir fark olmamasına rağmen evinde bilgisayar olan deney grubu öğrencilerinin ilkokuma yazma başarı puan ortalaması $(x=30.12)$, kontrol grubununkinden $(x=19.33)$ yüksektir.

Bilgisayar destekli öğretim yapılan deney grubundaki evlerinde bilgisayar olmayan öğrenciler ile geleneksel öğretim yapılan kontrol grubundaki evlerinde 
bilgisayar olmayan öğrencilerin ilkokuma yazma başarısı aritmetik ortalamaları arasında anlamlı bir fark bulunmuştur $(p<.05)$.

\section{Sonuç ve Tartışma}

Bilgisayar destekli öğretimin ilkokuma yazma başarısına etkisinin incelendiği bu araştırmanın birinci sorusu "Bilgisayar destekli öğretimin, ilköğretim birinci sınıf öğrencilerinin okuduğunu anlama, yazı, noktalama, yazma, sesli okuma ve ilkokuma yazma toplam başarısına etkisi var mıdır?" olarak belirtilmiştir. Araştırmadan elde edilen bulgular, bilgisayar destekli öğretimin yazı, noktalama ve okuma başarısında etkili olduğunu göstermiştir.

Bilgisayar destekli öğretimin geleneksel öğretime göre yazı başarısı açısından daha etkili olmasına ilişkin Kablan (2001) ilkokuma yazma öğretiminde PowerPoint programı kullanımı hakkında öğretmen görüşlerini aldığı çalışmasında, flash türü programlarda profesyonelce hazırlanmış animasyonlu çalışmaların yazı becerisinin geliştirilmesinde etkili olabileceğini belirtmiştir. Benzer olarak Haugland (1992), 4 ve 5 yaşlarındaki çocuklarla yaptığı araştırmada, bilgisayarın diğer uygun etkinliklerle desteklendiğinde çocukların yazı yazmak gibi karmaşık el becerilerinin gelişiminde yararlı olduğu sonucuna ulaşmıştır. $\mathrm{Bu}$ yargılar, bilgisayarın uygun etkinlikler kullanıldığında, birinci sınıf öğrencilerinin yazı becerilerinin gelişiminde yararlı olacağını desteklemektedir. Bu ifadelerden hareketle deney grubu öğrencilerinin yazı başarılarının kontrol grubu öğrencilerinkinden daha yüksek olması; öğrencilerin projeksiyon ve bilgisayardan yararlanılarak harflerin yazılış yönlerini ve yazılışlarını çeşitli renklendirmelerin yer aldığı animasyonlarla geniş ekranda izledikten sonra öğrendiklerini yazıya geçirmelerine, yapamadıklarında harflerin yazılış yönlerini ve yazılışlarını tekrar izleme olanağına sahip olmalarına bağlanabilir.

Bilgisayar destekli öğretimin noktalama işaretlerini doğru kullanmada da geleneksel öğretimden daha etkili olduğu sonucuna ulaşılmıştır. Bu durumun nedeni projeksiyon ve bilgisayardan yararlanılarak çeşitli müzikli ve animasyonlu eğitsel oyunlarla öğrencilerin noktalama işaretlerini yerleştirmeyi öğrenmeleri olabilir. Böylece bilgisayar destekli öğretimin öğrencilerin dikkatlerini daha çok çekerek motivasyonlarını artırdığı, görsellerle somutlaştırarak öğrenmenin daha kalıcı olmasını sağladığı düşünülebilir. Aydıner (2003)'ün çalışmasında da yazım kuralları farkındalığı açısından deney grubunun daha başarılı olması, bu sonucu desteklemektedir.

Araştırmada ulaşılan bir diğer sonuç, bilgisayar destekli öğretimin sesli okumada da geleneksel öğretimden daha etkili olmasıdır. Bu etki; öğrencilerin sesi hissetme ve hecelerden metinlere ulaşma sürecini PowerPoint sunuları, flash programları ve yazılımlar aracılığıyla sesli ve hareketli görseller, eğitsel oyunlar eşliğinde zevkli, eğlenceli ve ilgi duyarak yaşamalarından kaynaklanmış olabilir. Böylece okuma şifresini çözmeleri, hızlı ve nitelikli okumaya geçmeleri kolaylaşmış, öğrenmelerinin kalıcılığı artmış olabilir. Bu sonucu destekleyen Grabe ve Grabe (1996) tarafından yapılan bir araştırmada, sesler üstünde görsel renklendirmelerle ve konuşmalarla sunulan, sesli ve sessiz harfler arasındaki ilişkiyi öğretmek için hazırlanan yazılımın 
öğrenciler üzerinde sesleri öğrenmeleri açısından iyi bir etki bıraktığı görülmüştür. Wise, Olson ve Treiman (1990) tarafından yapılan bir araştırmada, ilkokuma yazma öğretimi için yazıların altı fosforlu ve renkli çizgilerle çizilerek, çeşitli şekillerle görselleştirilerek ve seslendirilerek hazırlanan bir yazılım kullanımı sonucunda öğrencilerin sesleri birleştirme becerilerinin geliştiği ve kelimeleri başka metinlerde gördüklerinde hemen okudukları görülmüştür. Daal ve Reitsma (2000) tarafından yapılan bir araştırmada da hazırlanan bir yazılımla sesleri öğrenen çocukların daha çok kelime okuyabildikleri ve harf sembollerini daha iyi tanıdıkları görülmüştür.

Benzer olarak Mitchell ve Fox (2001) tarafından yapılan bir araştırmada, örneklem grubundaki çocukların karıştırdıkları sesleri öğrenmeleri için hazırlanan bir bilgisayar yazılımının okuma problemleri yaşayan okul öncesi ve birinci sınıf çocuklarının ve ilk yılda okuma problemi çekmemiş okul öncesi ve birinci sınıf çocuklarının sesli okuma becerilerini geliştirdiği görülmüştür. Bilgisayarın öğretmene destek olduğu sonucuna varmışlardır. Tincup (2003) de deney ve kontrol gruplarında okuma güçlüğü çeken sekizer öğrenci ile gerçekleştirdiği çalışmada bilgisayar desteğiyle okuma öğretimi gören deney grubu öğrencilerinin sesli okuma başarılarının geleneksel öğretim gören kontrol grubu öğrencilerinkinden daha fazla olduğunu belirtmiştir.

Burns, Roe ve Ross (1996) tarafindan yapılan bir araştırmada ise bilgisayar destekli öğretimin pek çok sınıfta çocukların kelimeleri okumalarını verimli ve akıcı hâle getirdiği görülmüştür. Bilgisayar destekli öğretimin okuma akıcılığına etkisini araştıran bir başka yazar Ringenberg (2005) ise 2. sınıfa devam eden 33 öğrenciden oluşan deney grubunda bilgisayar destekli ve gözlemlenen bir okuma öğretimi uygularken, 32 öğrenciden oluşan kontrol grubunda gözlemlenmeyen geleneksel öğretim uygulamıştır. İlk 10 hafta süresince deney grubu yalnızca bir elektronik kitaptan, kelimeleri telaffuz eden ve okuyan bir elektronik kitaptan tercihler yaparak yararlanabilmiş, kontrol grubu ise fotokopi kâğıtlarından yararlanmıştır. İkinci 10 haftalık süreçte ise deney grubu bilgisayar destekli öğretimin yanı sıra fotokopi kâğıtlarından da yararlanmıştır ve gözlemlenmemişlerdir. Kontrol grubunun uygulamasında bir değişiklik olmamıştır. Sonuçta hem kontrol hem de deney grubunda birinci ve ikinci uygulama süreçlerinde gelişme görülmüştür. Birinci süreçte gelişim gösteren deney grubu ikinci süreçte de gelişim göstermeye devam etmiştir fakat birinci süreçte gözlemlenerek bilgisayar destekli okuma öğretimi gören deney grubunun gelişiminin kontrol grubununkinden anlamlı farklılaştığı bulgusu elde edilmiştir. Camacho (2002) da 20 1.sınıf öğrencisi ile 12 hafta boyunca bilgisayar destekli bir erken okuma programı uygulamış ve öğrencilerin okuma başarılarının arttığını görmüştür.

$\mathrm{Bu}$ araştırmanın bir başka sonucu bilgisayar destekli öğretimin geleneksel öğretim kadar okuduğunu anlama ve yazma başarılarında etkili olmamasıdır. Oysa 71'i deney, 68’i kontrol grubunda olan toplam 139 anasınıfı öğrencisine bilgisayar destekli program uygulayan Gingold (2000) programın öğrencilerin harf tanıma ve okuduğunu anlama becerilerine etkisini araştırmış ve bu becerilerinin gelişiminde geleneksel 
öğretim gören akranlarınınkine göre anlamlı fark tespit etmiştir. Hall, Hughes ve Filbert (2000) ise bilgisayar destekli öğretim sayesinde okumayı öğrenmede güçlük çeken öğrencilerin okumak için daha çok zaman ayırdıkları, harflerin şifresini çözerek okumayı öğrenmede ve okuduğunu anlamada geliştikleri sonuçlarına ulaşmıştır. Çatak (2006) da tez çalışması sonucunda PowerPoint sunu programıyla hazırlanan okuma materyalinin okuduğunu anlama becerisini geliştirdiğini belirlemiştir. Medwell (1996) ve Matthew (1997) de bilgisayar ortamındaki okuma materyali ile okumaya yeni başlayan çocukların okuduğunu anlama becerilerinin arttığı sonucuna ulaşmışlardır. Bu durumda deney ve kontrol grubu öğrencilerinin okuduğunu anlama becerilerinde farklılık görülmemesi, bu araştırmaların sonuçlarını desteklememektedir. Deney grubu öğrencilerinin okuduğunu anlama başarılarının kontrol grubundan daha yüksek olmaması, araştırma süresinin bir dönemle sınırlı olması ve başarı testinin yapıldı̆̆ dönem sonunda öğrencilerin sesleri henüz bitirmiş olmaları ve dolayısıyla bilgisayar destekli öğretimle yeterince okuduğunu anlama çalışması yapılamadığı için anlama becerilerinin gelişmemiş olabileceği ile açıklanabilir.

Bilgisayar destekli öğretimin geleneksel öğretim kadar etkili olmadığı bir diğer boyut yazma başarısıdır. Deney ve kontrol grupları arasında yazma başarısı açısından anlamlı bir fark olmaması, yazma başarısının artmasında belli stratejilerin izlendiği geleneksel öğretimin de etkili olabileceğini düşündürebilir. Zaten bu araştırmada olduğu gibi diğer araştırmalarda da (Bui, Schumaker, \& Deshler, 2006; Graham \& Harris, 2005; Graham \& Perrin, 2006; Malecki \& Jewell, 2003) geleneksel öğretimin yazma başarısını artırdığı sonucuna ulaşılmıştır.

Belirtilen yazarların ulaştığı sonuca ve bu araştırmanın yazma boyutuna ilişsin sonucuna zıt olarak Şimşek (2000) bilgisayar destekli yazılı anlatım çalışmalarının, geleneksel yöntemlerle yapılan yazılı anlatım çalışmalarından daha etkili olduğu sonucuna ulaşmıştır.

Şimşek (2000)’nin ulaştığı sonucun tersine bu araştırmada bilgisayar destekli ilkokuma yazma öğretiminin yazma başarısında etkili olmayışının bir diğer nedeni okuduğunu anlama çalışmalarının yetersizliği olabilir. Birinci dönem sonu sesler henüz bitirildiği için öğretmenler tarafından yeterince okuduğunu anlama çalışması yapılamaması nedeniyle bilgisayar destekli ilkokuma yazma öğretimi gören deney grubu öğrencilerinde okuduğunu anlama becerisinin gelişememesine bağlı olarak yazma becerisinin de gelişememiş olabileceği düşünülebilir.

Araştırmada ilkokuma yazma toplam başarısına ilişkin olarak, bilgisayar destekli öğretimin ilkokuma yazma başarısında etkili olduğu sonucuna ulaşılmıştır. Bu sonuç, bilgisayar destekli öğretimin ilkokuma yazma öğretimindeki etkililiğini açıkça ortaya koymakta ve pek çok araştırma (Anderson-Inman \& Horney, 1998; Barker \& Torgesen, 1995; Burns, Roe, \& Ross, 1996; Daal \& Reitsma, 2000; Grabe \& Grabe, 1996; Haugland, 1992; Kablan, 2001; Matthew, 1997; McKenna \& Watkins, 1996; Medwell, 1996; Mitchell \& Fox, 2001; Reitsma, 1988; Reitsma \& Wesselling, 1998; Wise, Olson, \& Treiman, 1990) sonucunu desteklemektedir. Örneğin; Hollanda'da Reitsma ve Wesselling (1998) tarafından yapılan bir araştırmada hazırlanan bir yazılımla sesleri 
öğrenen çocukların okuma yazma performanslarının yazılım kullanılmayanlarınkinden daha yüksek olduğu görülmüştür. Amerika'da Barker ve Torgesen (1995) tarafından yapılan bir araştırmada, konuşmaları yazıya, yazıları konuşmaya çeviren ve sesleri öğreten yazılımların desteğiyle okuma yazmayı öğrenen öğrencilerin kelimeleri okumada ve harf sembollerini tanımada yazılımın kullanılmadığı öğrencilerden daha başarılı oldukları görülmüştür. Benzer olarak Yalçın (2006) tarafından hazırlanan tez çalışmasında, konuşma tanıma teknolojisi yardımıyla ilköğretim birinci sınıf öğrencilerine ilkokuma yazma öğretimi için bir yazılım geliştirilmiştir. 30'a yakın sesli komut ile program kontrol edilebilirken konuşulan 10000 kadar cümlenin veya kelimenin tanındığı bilgisayara bağlı bir mikrofon aracılığıyla öğretmenin veya öğrencinin konuşması ekrana yazılabilmektedir. Bu yazılım sayesinde öğretmenin ilkokuma yazma öğretimi yapabileceği, öğretmen ve öğrenci açısından etkili bir ilkokuma yazma süreci sağlanabileceği düşünülmüsstür.

Waldman (1995) ise Kuzey Kaliforniya'da bir okulda gerçekleştirilen çalışmada çokluortam okuryazarlık araçlarının birinci sınıf öğrencilerinin okuma ve yazma başarılarına etkisine bakmıştır. Bu amaçla çalışmada metin, grafik, ses ve etkileşim, geribildirim, anlamı yapılandırma özelliklerine sahip sesler gibi okuma yazma öğrenmek için gerekli niteliklerle bütünleştirilmiş bir çokluortam aracı kullanılmıştır. Çalışmanın yarı deneysel kısmında önce üç ay, sonra beş ay uygulama sonrasında veriler iki kere toplanmış, nitel kısmında ise öğretmen ve öğrencilerin görüşleri alınmıştır. Çalışma grubunu 56 deney, 84 kontrol grubu öğrencileri olmak üzere toplam 140 öğrenci oluşturmuştur. Veriler, basit kelimeler, dil gelişimi ve basit kelimelerden elde edilen bileşik kelimeler analizini kapsayan beceri testi ile düzenleme, gelişim ve mekanik incelemeyi içeren analitik yazı değerlendirmesi kullanılarak toplanmıştır. Sonuçta çokluortamın basit kelime gelişiminde etkisi görülürken dil ve bileşik yapılı kelime gelişiminde etkisi görülmemiştir. Görüşlerinden elde edilen bulgularla öğretmen ve öğrencilerin çokluortamın özellikleri sayesinde motive oldukları ve bu motivasyon sayesinde okuma, yazma ve bilgisayar teknolojisine ilişkin olumlu tutum geliştirdikleri belirlenmiştir. Benzer olarak Orhan (2007)'nin ülkemizde bilgisayar destekli ilkokuma yazma öğretimi yapan 12 öğretmenin yöntemin ilkokuma yazma başarısına etkisine ilişkin görüşlerinin alındığı çalışmada öğretmenler; bilgisayar destekli ilkokuma yazma öğretiminin öğrenmede kalıcılığı, motivasyonu, konuya dikkati, çoklu zekaya hitap edilebilirliği artırma, harfleri yazma hatalarını azaltma, konulara takılmayı azaltarak zaman kazandırma gibi yararlarından söz etmişlerdir. Özellikle animasyonlu ve sesli görüntülerin öğrencilerin daha çok dikkatini çektiğini ifade etmişlerdir.

Araştırmanın ikinci sorusu "Evlerinde bilgisayar olan ve olmayan gruplarda, bilgisayar destekli öğretimin ilkokuma yazma başarısına etkisi var mıdır?”şeklinde belirtilmiştir. Elde edilen bulgulara göre evinde bilgisayar olmayan deney grubu öğrencilerinin ilkokuma yazmada, evinde bilgisayar olmayan kontrol grubu öğrencilerinden daha başarılı olduğu tespit edilmiştir. Başka bir deyişle, bilgisayar destekli öğretimin evinde bilgisayar olmayan öğrencilerin ilkokuma yazma başarılarında geleneksel öğretim gören öğrencilerinkinden daha etkili olduğu görülmüştür. Bu etki, 
sınıf ortamındaki öğretimi destekleyen bilgisayar ve diğer bilgi teknolojileri kullanımının evinde bilgisayar olmayan deney grubu öğrencilerinin dikkatlerini daha fazla çekip motivasyonlarını artırmasından kaynaklanmış olabilir.

İkinci soruya ilişkin bir başka sonuç, evinde bilgisayar olan deney ve kontrol grubu öğrencilerinin ilkokuma yazma başarılarında anlamlı bir fark olmamasıdır. Bu bağlamda bilgisayar destekli öğretimin evinde bilgisayar olan öğrencilerin ilkokuma yazma başarılarında etkili olmadığı söylenebilir. Bu durum evinde bilgisayar olan deney grubu öğrencilerinin derslerdeki dikkat ve motivasyon düzeylerinin amaçsız ve sistemsiz bilgisayar kullanımından olumsuz etkilenmesi ile açıklanabilir. Belirtilen nedenle ilkokuma yazma başarısı açısından kontrol grubu öğrencileriyle aralarında anlamlı bir fark oluşmamış olabilir.

\section{Öneriler}

Araştırmadan elde edilen sonuçlar göz önüne alınarak, ülkemizde ilkokuma yazma öğretiminde bilgisayar destekli öğretime yer verilmesinin, ilkokuma yazmada öğrenci başarısını sağlamada ve artırmada oldukça önemli bir yeri olduğu söylenebilir fakat gelişmiş ülkelerde ilkokuma yazma öğretiminde sınıfta bulunan tek bilgisayarın etkili olmadığına, interaktif öğretimin gereğine inanılmaktadır. Bu amaçla ilkokuma yazma başarısını artırmak üzere öğretmenler tarafından sınıfta bir bilgisayar ve projeksiyonla desteklenen ilkokuma yazma öğretimi yerine, bilişim teknolojisi sınıflarında interaktif olarak hazırlanmış yazılımlar desteği ile öğretim yapılabilir. Belirtilen önerinin etkili olabilmesi için alan uzmanları ile işbirliği yaparak yazılım uzmanları tarafından ilkokuma yazma öğretimine ilişkin profesyonel yazılımların geliştirilmesi ve alandaki yazılım sayısının artırılması yerinde olacaktır.

Öğretimin hem programla bütünleştirilebilmesi hem de firsat eşitliğinin sağlanması için ders kitapları; yazılımlar, sunular gibi bilgisayar destekli öğretim materyallerinin kullanımına uygun olarak düzenlenebilir. Hazırlanacak materyal setleri ders kitapları ile birlikte okullara ulaştırılabilir. $\mathrm{Bu}$ noktada öğretmenlerin genel bilgisayar bilgi ve becerisinin sağlanmasının ardından, onlara bilgisayar destekli öğretime ilkokuma yazma uygulamalarında niçin, nasıl, ne kadar yer vereceklerine ilişkin ciddi bir hizmet içi eğitimin verilmesi gerekli olacaktır. Bununla birlikte öğretmenler aracılığıyla öğrenci velileri bilgilendirilerek, evinde bilgisayar olan öğrencilerin, velilerinin desteği ile bilgisayar destekli ilkokuma yazma materyallerinden yararlanmaları sağlanabilir.

Son olarak, bilgisayar destekli öğretimin ilkokuma yazma başarısına etkisinin araştırıldığı bu çalışma, birinci dönem süresince uygulanmıştır. İlgili araştırmacılar tarafından bu çalışma bir eğitim-öğretim yılını kapsayacak biçimde sürdürülerek deney ve kontrol grubunun okuduğunu anlama ve yazma başarıları arasında farklılık olup olmamasının nedenleri daha açık ortaya konulabilir. Bu nedenle ilkokuma yazma başarısını etkileyen nedenleri belirleyerek başarıyı artırmak üzere bu çalışmaya benzer uygulamaların gerçekleştirilmesine devam edilmesi önerilebilir. 


\section{Kaynakça}

Akyol, H. (2005). Türkçe ilkokuma yazma öğretimi (4.bask1). Ankara: PegemA Yayınları.

Anderson-Inman, L. \& Horney, M. (1998). Transforming text for at-risk readers. In D. Reinking, L. Labbo, M. McKenna \& R. Kieffer (Eds.), Handbook of literacy and technology: technological transformations in a post-typographic world (pp. 15-43). Mahwah, NJ: Erlbaum.

Aydıner, N. (2003). Anlamlandırma stratejisinin ilkokuma yazmaya etkisi (Yayımlanmamış doktora tezi). Hacettepe Üniversitesi, Ankara.

Barker, T. \& Torgesen, J. (1995). An evaluation of computer-assisted instruction in phonological awareness with below average readers. Journal of Educational Computing Research, 13, 89-103.

Brooks, G. (2000). The influence of preschool experience on early literacy attainment: The research evidence. Retrieved from http://www.literacytrust.org.uk/Research/brooks.html.

Bui, Y. N., Schumaker, J. B., \& Deshler, D. D. (2006). The effects of a strategic writing program for students with and without learning disabilities in inclusive fifth-grade classes. Learning Disabilities Research and Practice, 21(4), 244-260.

Burns, P.C., Roe, B.D., \& Ross, E.P. (1996). Teaching reading in today's elementary schools (7th ed.). Boston, MA: Houghton Mifflin Company.

Calp, M. (2003). İlkokuma yazma öğretimi. Konya: Ĕ̆itim Kitabevi Yayınları.

Camacho, M. A. (2002). The effects of Waterford early reading program on reading achievement of first-grade students. Masters Abstracts International, 40(5), 1114.

Clark, R. (1991). When researchers swim upstream: Reflections on an unpopular argument about learning from media. Educational Technology, 18, 34-39.

Connor, C. M., Son, S., Hindman, A., \& Morrison, F. J. (2005). Teacher qualifications, classroom practices, family characteristics and preschool experience: Complex effects on first graders' vocabulary and early reading outcomes. Journal of School Psychology, 43, 343-375.

Cooper, J. D. (1997). Literacy: Helping children construct meaning. Retrieved from http://www.nwrel.org/scpd/sirs/5/cu10.html

Cotton, K. (1991). Computer-assisted instruction. Retrieved from http://www.nwrel.org/scpd/sirs/5/cu10.html

Cunningham, A. E. \& Stanovich, K. E. (1998). Early reading acquisition and its relation to reading experience and ability 10 years later. Developmental Psychology, 33, 934-945.

Çakır, T. (2004). Çocukta dil gelişimi ve dil gelişim kuramları. Sakarya Üniversitesi Ë̆itim Fakültesi Dergisi, 7, 139-164. 
Çatak, A. A. (2006). Powerpoint sunu programıla hazırlanan okuma materyalinin eğitilebilir zihin engelli ögrencilerin okuduğunu anlama becerisi üzerindeki etkisi (Yayımlanmamış yüksek lisans tezi). Abant İzzet Baysal Üniversitesi, Bolu.

Echols, L. D., West, R. F., Stanovich, K. E., \& Zehr, K. S. (1996). Using children’s literacy activities to predict growth in verbal cognitive skills: A longitudinal investigation. Journal of Educational Psychology, 88, 296-304.

Friend, C. L. \& Cole, C. L. (1990). Learner control in computer-based instruction: A current literature review. Educational Technology, 30(11), 47-49.

Gambrell, L., B., Morrow, L., M., \& Pennington, C. (2000). Early childhood and elementary literature-based instruction: Current perspectives and special issues. Reading Online, 5(6). Retrieved from http://www.readingonline.org/articles/art_index.asp?HREF=handbook/gambrell/ind ex.html

Gingold, C. (2000). A comparison of the impact of a computer-based program with the impact of traditional instructional methods on emergent reading skills of prekindergartners. Dissertation Abstracts International, 61(3), 874A.

Gönen, M., Öncü, E., \& Işıtan, S. (2004). İlköğretim 5, 6, 7. sınıflarda okuma alışkanlıklarının incelenmesi. Milli Eğitim Dergisi, 164, 3-16.

Grabe, C. \& Grabe, M. (1996). Integrating technology for meaningful learning (1st ed.). Boston, MA: Houghton Mifflin.

Graham, S. \& Harris, K. R. (2005). Improving the writing performance of young struggling writers: Theoretical and programmatic research from the center on accelerating student learning. The Journal of Special Education, 39(1), 19-33. doi: $10.1177 / 00224669050390010301$

Graham, S. \& Perrin, D. (2006). Writing next: Effective strategies to improve writing of adolescent in middle and high school- A report to Carnegie Corporation of New York. Washington, DC: Alliance for Excellence in Education.

Güneş, F. (2005). Niçin ses temelli cümle yöntemi? Eğitimde Yansımalar: 8. Erciyes Üniversitesi Yeni İlköğretim Programlarını Değerlendirme Sempozyumu Bildiriler Kitabl, 136-145. Ankara: Sim Matbaası.

Hall, T. E., Hughes, C. A., \& Filbert, M. (2000). Computer-assisted instruction in reading for students with learning disabilities: A research synthesis. Education \& Treatment of Children, 23(2), 173-193.

Haugland, S. (1992). The effect of computer software on preschool children's developmental gains. Journal of Computing in Childhood Education, 3(1), 15-30. Retrieved from http://www.eduplace.com/rdg/res/literacy.

Kablan, Z. (2001). Powerpoint sunu programıyla hazırlanan Türkçe ilkokuma yazma ögretim materyali hakkındaki ögretmen görüşleri (Yayımlanmamış yüksek lisans tezi). Yıldız Teknik Üniversitesi, İstanbul.

Karasar, N. (2005). Bilimsel araştırma yöntemi (15. bs.). Ankara: Nobel Yayını. 
Koç, A. A., Taylan, E. E., \& Bekman, S. (2002). Türkiye'de okul öncesi ĕgitimi. http://www.7cokgec.org/files/turkiyede_okul_oncesi_egitimi_duyuruları_iht_sapta nmasi.pdf adresinden alınmıştır.

Kulik, J. (1994). Meta-analytic studies of findings on computer-based instruction. In E. L. Baker \& H. F. O'Neil (Eds.), Technology assessment in education and training (pp. 9-33). Hillside, NJ: Lawrence Erlbaum Associates.

Malecki, C. K. \& Jewell, J. (2003). Developmental gender and practical considerations in scoring curriculum based measurement writing probes. Psychology in the Schools, 40(4), 379-390. doi: 10.1002/pits.10096

Mathes, P. G., Denton, C. A., Fletcher, J. M., Anthony, J. L., Francis, D. J., \& Schatschneider, C. (2005). The effects of theoretically different instruction and student characteristics on the skills of struggling readers. Reading Research Quarterly, 40, 148-182.

Matthew, K. (1997). A comparison of the influence of interactive CD-ROM storybooks and traditional print storybooks on reading comprehension. Journal of Research on Computing in Education, 29(3), 263-275.

McKenna, M. C. \& Watkins, J. (1996, April). Using talking books with beginning readers. Paper presented at the 41st International Reading Association Annual Convention, New Orleans, LA.

Milli Eğitim Bakanlığı. (2005). Illköğretim (1-5) Türkçe ders programı kılavuzu. İstanbul: Milli Eğitim Basımevi.

Medwell, J. (1996). Talking books and reading. Reading, 30(1), 41-46.

Mitchell, M. J. \& Fox, B. J. (2001). The effects of computer software for developing phonological awareness in low-progress readers. Reading Research and Instruction, 40(4), 315-332.

Orhan, H. G. (2007). Bilgisayar destekli ilkokuma yazma öğretimine ilişkin öğretmen görüşlerinin incelenmesi. 1. Uluslararası Bilgisayar ve Öğretim Teknolojileri Sempozyumunda sunulmuş sözlü bildiri, Çanakkale 18 Mart Üniversitesi, Çanakkale, Türkiye.

Özer, R. (1998). Rehber öğretmenlerin tükenmişlik düzeyi nedenleri ve çeşitli değişkenlere göre incelenmesi (Yayımlanmış yüksek lisans tezi). Karadeniz Teknik Üniversitesi, Trabzon.

Öztunç, S. (1994). Okuma kavramları testi’nin Türk çocuklarına uyarlanması. (Yayımlanmamış yüksek lisans tezi). Marmara Üniversitesi, İstanbul.

Paivio, A. (2006). Dual coding theory and education. Retrieved from http://www.umich.edu/ rdytolrn/pathwaysconference/presentations/paivio.pdf

Reitsma, P. \& Wesseling, R. (1998). Effects of computer-sssisted training of blending skills in kindergartners. Retrieved from http://www.nwrel.org/scpd/sirs/5/cu10.html

Rıza, E. T. (1997). Eğitim teknolojisi uygulamaları (4. bs.). İzmir: Anadolu Matbaası. 
Ringenberg, M. L. (2005). Developing reading fluency with computer-assisted reading practice. Dissertation Abstracts International, 66(3), 894A.

Savaş, B. (2006). Okuma eğitimi ve çocuklarda dil gelişimi (2. bs.). İstanbul: Alfa Yayınları.

Şenol, M. (2001). Okuma ve yazma öğretiminin kaynakları. Afyon Kocatepe Üniversitesi Sosyal Bilimler Dergisi, 2(2), 205-219.

Tincup, M. J. (2003). Evaluating the effects of a computer-based phonological processing intervention on phonological processing and reading achievement: A pilot study. Dissertation Abstracts International, 64, 845.

Torgesen, J. K. \& Burgess, S. R. (1998). Consistency of reading-related phonological processes throughout early childhood: Evidence from longitudinal-correlational and instructional studies. In J. L Metsala \& L. C. Ehri (Eds.), Word recognition in beginning literacy (pp. 161-188). Mahwah, NJ: Lawrence Erlbaum.

Tortop, R. (2003). Uygulamalı örnekleriyle ilkokuma yazma kllavuzu. İzmir: Top Yayıncilik.

Van Daal, V. H. P. \& Reitsma, P. (2000). Computer-sssisted learning to read and spell: Result from two pilot studies. Journal of Research in Reading, 23, 181-193.

Waldman, H. L. (1995). The effects of a multimedia literacy tool on first-grade reading and writing achievement (Unpublished doctoral dissertation). The University of San Francisco, San Francisco.

Willis, J. W. (2008). Qualitative research methods in education and education technology. USA: Age Publishing Inc.

Wise, B. W., Olson, R. K., \& Treiman, R. (1990). Subsyllabic units as aids in beginning readers word learning onset-rime versus post-vowel segmentation. Journal of Experimental Child Psychology, 49, 1-19.

Yalçın, N. (2006). Konuşma tanıma teknolojisi yardımıyla ilköğretim birinci sınıf ögrencilerine ilkokuma yazma öğretimi için bir yazllım geliştirme (Yayımlanmamış doktora tezi). Gazi Üniversitesi, Ankara.

Yalın, H. (2003). Öğretim teknolojileri ve materyal geliştirme (8. bs.). Ankara: Nobel Yayınları.

Yılmaz, B. (1995). Okuyan aile okuyan birey. Yaşadıkça Eğitim Dergisi, 41, 58-67.

Yiğit, B. (2007). Okul aile-çevre ilişkisi ve eğitimdeki önemi. Eğitime Bakış Dergisi, 3(8), 55-61. 